\title{
Corporate social responsibility in Bolivia: meanings and consequences
}

\author{
Boris Herbas Torrico ${ }^{1}$, Björn Frank ${ }^{2^{*}}$ and Carlos Arandia Tavera ${ }^{1}$
}

\begin{abstract}
Background: Corporate social responsibility (CSR) has been studied extensively in developed countries. However, although most of the world's consumers live in developing countries, the study of CSR in developing countries in general, and in Bolivia in particular, still is very limited. Developing countries are characterized by widespread poverty, corruption, inequality, social exploitation, and environmental pollution and, consequently, offer abundant opportunities for CSR. In addition, research on CSR in developing countries has the potential to promote equality, social justice, transparency, and accountability by holding frequently irresponsible local and international organizations to account. For that purpose, this study explores the nature of CSR practices and their effectiveness in influencing consumer attitudes in Bolivia as the least developed among the developing countries in the Americas. To this end, this study uses data collected in Bolivia through both structured surveys (quantitative data) and unstructured questionnaires/in-depth interviews (qualitative data). Using structural equation modeling of the quantitative data on two product categories and multiple brand contexts from 1016 consumers, this study tests a series of hypotheses on the consequences of CSR practices in developing countries. The results indicate that CSR practices exert both a direct influence on customer satisfaction and an indirect, mediated influence on customer loyalty. Moreover, the results of qualitative data analysis suggest that multinational companies and young managers are leading the way in implementing CSR practices in Bolivia. Managerial implications are discussed.
\end{abstract}

Keywords: Corporate social responsibility, Customer satisfaction, Customer loyalty, Developing country, Eco-friendly practices, Environmental sustainability, Ethical behavior, Latin America, Recycling convenience, Social sustainability

\section{Introduction}

The 2008 global financial crisis has increased the trend for organizations to identify themselves as responsible and trustworthy. For example, according to Bhattacharya (2009), many organizations have come to pursue activities to measure and reduce their carbon footprint, thus increasing their value to society. On the management level, organizations are moving away from a firm-centric type of strategy determined solely by executive boards, to a more inclusive type of cooperative value creation emphasizing cooperation with stakeholders (Bhattacharya 2009). Corporate social responsibility (CSR) practices that benefit direct and indirect stakeholders such as customers, employees, society, and the environment are a key pillar in this trend toward cooperative value creation. Such CSR

\footnotetext{
* Correspondence:

${ }^{2}$ Graduate School of Commerce, Waseda University, 1-6-1 Nishi-Waseda,

Shinjuku-ku, Tokyo 169-8050, Japan

Full list of author information is available at the end of the article
}

practices may appear as selfless actions, but they have the potential to benefit firms through positive stakeholder reactions beneficial to the organization. For instance, CSR practices cause consumers to feel proud to be affiliated with the focal, apparently socially responsible company and thus strengthen consumers' brand identification, which can lead to greater sales and revenues (Bhattacharya and Sen 2004).

While the literature on CSR predominantly focuses on the effects of CSR in developed countries, there is a gap in exploring the effects of CSR in developing countries. According to Pisani et al. (2017), less than $10 \%$ of the CSR literature primarily focuses on developing countries, potentially due to less public pressure on firms to report CSR practices in developing countries (Ali 2017), thus reducing the availability of CSR data for scholarly research. In line with this assumption, research finds that firms in developing countries tend to report CSR practices only reluctantly upon pressure from powerful stakeholders such as government 
agencies (Hossain et al. 2017) and international stakeholders (Jamali et al. 2017).

As developing countries comprise the majority of the world's population, generating knowledge of the role of CSR in developing countries would be highly relevant to managers and policy-makers. In particular, virtually no studies illuminate the effects of CSR practices by companies in Latin American countries (Haslam 2007). Furthermore, Pisani et al. (2017) report that the CSR literature includes only 43 studies on Latin American countries and has not yet addressed a few Latin American countries such as Bolivia. According to De Olivera (2006), CSR in Latin America has been shaped heavily by socio-economic and political conditions that aggravate environmental and social problems such as deforestation, unemployment, inequality, and crime. Thus, CSR practices are regarded as hope for positive change in the face of persistent poverty, environmental degradation, corruption, and economic stagnation.

In the specific case of Bolivia, the least developed country in the Americas (IMF 2017), CSR practices arrived 20 years ago. Since then, Bolivian organizations have come to understand that CSR practices consist of not only philanthropy but of a holistic management system that adds value to stakeholders (Sanchez 2016). Although many Bolivian organizations nowadays attempt to include CSR practices in their marketing strategy, there is a lack of research to determine whether those practices have any influence on Bolivian consumers and thus on whether those practices have the potential to pay off financially.

To fill this significant gap in the CSR literature, where studies on developing countries are scarce, our study explores the influence of CSR practices on consumer attitudes in Bolivia as a developing Latin American country that has not yet been studied. For that purpose, we develop a model (see Fig. 1) that describes the influences of CSR practices (recycling convenience, eco-friendly practices, and ethical behavior) on customer satisfaction and customer loyalty. To test this model, we perform structural equation modeling of original quantitative data on two product categories collected from 1016 consumers in Bolivia. To provide further verification of our results and to extend these results with local practitioner expertise, we also use qualitative data collected through in-depth interviews with CSR experts in Bolivia.

\section{Theoretical background and hypotheses} Theoretical foundation

According to Rahman (2008), there is no dominant theoretical perspective for the study of CSR practices. However, Rahman (2008) suggests three main approaches to studying CSR practices: political economy theory, legitimacy theory, and stakeholder theory. Although other theories exist (such as decision-usefulness theory, positive accounting theory, and agency theory), Gray et al. (1995) argue that those theories are not useful for the study of CSR practices because CSR is motivated by market failures and the desire to change current business practices. Bowen (1953) propose that managers should be responsible for their actions in a sphere wider than the profit-and-loss statement. As a consequence, according to Castaldo et al. (2009), several schools of managerial thought have emerged, and most of the conceptualizations of CSR relate to stakeholders.

A review from Frynas and Yamahaki (2016) finds that stakeholder theory dominates the study of external drivers of CSR practices. According to Freeman (1994), stakeholder theory relates to the study of interest groups that can affect, or be affected by, the firm's activities, such as customers. Specifically, according to Berman et al. (1999), stakeholder theory suggests that firms are interested in their consumers because consumers react to corporate behaviors and increased purchases by consumers drive financial performance. Marketing studies have applied stakeholder theory when studying the effects of CSR types such as environmental protection, community volunteer activities, natural resource saving,

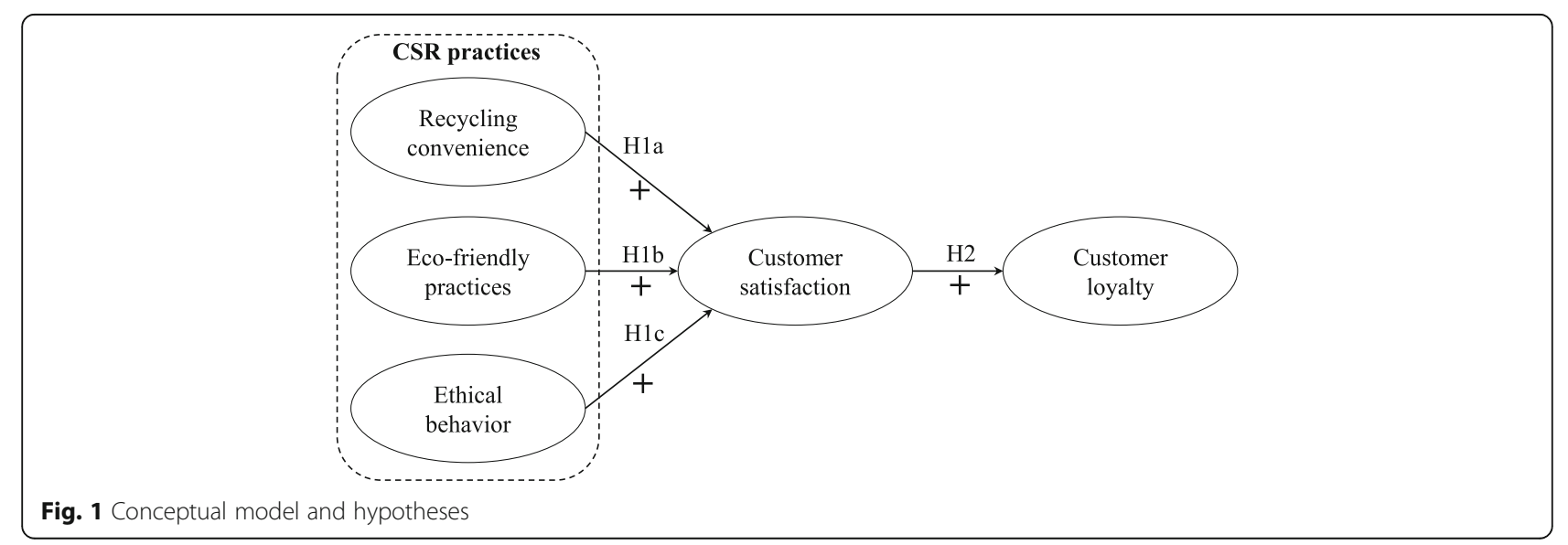


and social charities (Handelman and Arnold 1999; Quazi and O'Brien 2000). Some of these studies find evidence of an influence of CSR practices on consumer behavior (Bhattacharya and Sen 2004; Haddock-Fraser and Tourelle 2010; Maignan 2001), consumer product responses (Brown 1998), and purchase intentions (Barnes et al. 2005). Conversely, consumers' ethical values and expectations for CSR practices also influence manager attitudes (Mandhachitara and Poolthong 2011). Therefore, this stream of literature suggests that stakeholder theory relates to consumers (Berman et al. 1999) and thus is appropriate for the study of CSR practices and their relationships with marketing outcomes such as customer satisfaction.

In addition to stakeholder theory, signaling theory may serve as an alternative framework for the study of the customer impact of CSR practices. Signaling theory emphasizes that information influences consumer decision-making processes. Consumers make decisions based on public information, which is freely available, and private information, which is available for only a part of the public. According to Connely (2011), information asymmetries arise between those who hold private information (firms) and those who potentially could make better decisions if they had it (consumers). Thus, signaling theory is concerned with reducing such information asymmetries between firms and consumers. Some marketing studies argue that organizations adopt CSR practices to signal intangible attributes to their consumers (Frombrun et al. 2000; Su et al. 2016) and that consumers value the intangible attributes which CSR practices convey (Surroca et al. 2010). Moreover, in developing countries, due to the lack of quality information on capital, labor, and product markets, firms tend to form closed networks to better control information (Miller et al. 2009). Thus, CSR practices have the potential to effectively signal intangible attributes to consumers. For instance, according to Doh et al. (2016), multinational firms in developing countries pursue CSR practices as a signaling mechanism to (a) gain legitimacy, (b) overcome liabilities of foreignness, and (c) obtain a license to operate. In line with this argument for a strong effect of CSR practices on consumer attitudes in developing countries, consumer culture theory (Arnould and Thompson 2005) suggests that consumer behavior in general (not only concerning CSR) converges across countries as the Internet improves access to information and consumers align their identities with the structural imperatives of a consumer-driven global economy. Therefore, we predict considerable effects of CSR practices on customer satisfaction and loyalty even in the hitherto unexplored context of Bolivia as the least developed country of the Americas (IMF 2017).
Effects of CSR practices on customer satisfaction (H1)

Based on the above theoretical foundation, we posit that firms use CSR practices to increase customer satisfaction and consequential customer loyalty (stakeholder theory, signaling theory). We also posit that these effects, compared to the abundant research results in developed countries, are of a similar (consumer culture theory) or even greater magnitude (signaling theory) in developing countries.

The global CSR literature strongly supports influences of CSR practices on consumer attitudes and purchase intentions, although most of these studies focus on developed countries. Chung et al. (2015) suggest that consumers evaluate organizations and products in terms of their CSR practices. Moreover, different studies find that CSR practices have a significant influence on customer-related outcomes (Bhattacharya and Sen 2004). For example, Creyer and Ross (1997) find that CSR practices influence consumers' purchase decisions. Additionally, according to Creyer and Ross (1997), consumers are willing to pay higher prices to reward organizations' CSR practices. Moreover, according to Luo and Bhattacharya (2006), customers derive value and consequently higher satisfaction from products that are made by socially responsible organizations. In addition, Bhattacharya and Sen (2004) suggest that CSR practices make consumers perceive an organization to have a better reputation, a stronger personal connection, and a higher fit between the organization and their personal causes. Furthermore, Maignan and Ferrell (2001) suggest that CSR practices have a positive impact on a consumer's evaluation of products. Similarly, Brown and Dacin (1997) propose that CSR associations influence product evaluations through the organization's image. Moreover, de los Salmones et al. (2005) report that CSR practices influence the overall evaluation of services. In addition, Sureshchandar et al. (2002) propose that CSR practices should be understood as an organization's ethical behavior, and thus as another component of quality. In other words, an organization whose behavior is perceived to be ethically correct transmits trust to its customers and positively influences their evaluations (de los Salmones et al. 2005). Therefore, based on studies from developed countries, the extant literature suggests that CSR practices positively influence consumer attitudes such as customer satisfaction. Drawing on overwhelming theoretical support and our theoretical foundation, we likewise argue for positive effects of CSR practices on customer satisfaction in developing countries (H1).

In particular, our study considers three types of CSR practices that Ward et al. (2007) consider as being of special importance to developing countries: recycling convenience (H1a), environmentally responsible/ecofriendly practices $(\mathrm{H} 1 \mathrm{~b})$, and ethical behavior ( $\mathrm{H} 1 \mathrm{c})$. First, as many firms in developing countries habitually 
violate legal obligations and mistreat their workers, ethical behavior (H1c) in the form of legal compliance and social standards in labor relationship serves as the first milestone in a CSR strategy (Ward et al. 2007). Second, since recycling practices often fail due to consumers' low incomes and a consequential lack of willingness to invest time and costs on behalf of higher-level environmental goals (Wang et al. 2011), recycling convenience (H1a) facilitates the consumer participation in recycling activities in developing countries. Third, environmentally responsible practices $(\mathrm{H} 1 \mathrm{~b})$ are highly relevant to developing countries where firms frequently are responsible for massive environmental pollution, which compromises living conditions (Ward et al. 2007).

\section{Effect of recycling convenience on customer satisfaction (H1a)}

According to Berry et al. (2002), convenience is the ability to reduce consumers' non-monetary costs (i.e., time, energy, and effort) when purchasing products or services. Regarding recycling convenience, Ando and Gosselin (2005) find evidence that links convenience with recycling rates. Moreover, Sidique et al. (2010) propose that recycling is increased when consumers perceive it as a convenient activity. Additionally, Domina and Koch (2002) find that convenience is an important determinant of recycling behavior. Similarly, Vining and Ebreo (1990) suggest the existence of differences between recyclers and non-recyclers due to recycling convenience. Hence, the available literature indicates that recycling convenience is an antecedent of recycling behavior and thus determines the consumption of recyclable products.

In this broad literature on recycling, a number of studies link recycling to consumer attitudes. Mobley et al. (1995) suggest that purchases of recyclable products depend on overall affect toward recycling. Moreover, Minton and Rose (1997) find that attitudes are determinants of the consumption of recyclable products. In addition, Biswas et al. (2000) suggest that consumer attitudes toward recycling influence recycling shopping behavior. Furthermore, Frank et al. (2012) and Srivastava and Kaul (2014) suggest that convenience influences attitudes such as customer satisfaction. While these studies reflect the situation of developed countries, we draw on our theoretical foundation to hypothesize analogously that recycling convenience positively influences customer satisfaction in developing countries (H1a).

Recycling practices frequently fail in developing countries where consumers have low incomes and consequentially lack the willingness to invest time and costs on behalf of higher-level environmental goals (Wang et al. 2011). In terms of stakeholder theory, a firm's provision of recycling convenience reflects an understanding of consumer difficulties and enables consumers to address prevalent waste problems, thus rewarding the firm by a positive consumer reaction in the form of higher customer satisfaction. In terms of signaling theory, a firm's provision of recycling convenience signals a better understanding of consumer concerns and a higher capability to create value for consumers and society.

\section{Effect of eco-friendly practices on customer satisfaction (H1b)}

Nowadays, consumers recognize the importance of protecting the environment. As a consequence, environmentalism has become a major issue in the marketplace, making consumers more ecologically conscious and inducing them to buy eco-friendly products (Kalafatis et al. 1999). The literature finds that a firm's eco-friendly practices strongly enhance eco-conscious consumers' satisfaction level (Laroche et al. 2001; Han et al. 2009; Kalafatis et al. 1999; Manaktola and Jauhari 2007), thus leading to higher average customer satisfaction. In terms of stakeholder theory, firms engaging in eco-friendly practices take their eco-conscious consumers' value preferences seriously and are rewarded with a positive consumer response.

Moreover, according to Cetindamar (2007), ecofriendly practices require organizations to invest in better technology, methods, tools, and raw materials, helping them to become more innovative and achieve competitive advantage (Porter and Linde 1995) reflected by lower costs and improved customer attitudes (Griffin and Mahon 1997). In terms of signaling theory, a firm's eco-friendly practices thus signal advanced capabilities, which likely is particularly effective to differentiate the firm in developing countries where many firms are perceived as not having such capabilities. Consequently, we predict that consumer perceptions of corporate ecofriendly practices positively influence customer satisfaction in developing countries (H1b).

\section{Effect of ethical behavior on customer satisfaction ( $\mathrm{H} 1 \mathrm{c})$}

Global competition has pressured organizations to cut labor costs, and some organizations have responded to this pressure by implementing abusive labor practices (Rudell 2006). Governments, organizations, and consumers have benefited directly and indirectly from such unfair labor practices. According to Rudell (2006), consumers play a main role in ensuring an ethical marketplace through socially conscious and informed product selection. For example, Roberts (1995) proposes that socially conscious consumers express their social concerns through their purchasing power (Roberts 1995). Therefore, consumers with high ethical standards react to an organization's degree of ethical behavior regarding different dimensions, such as the perceived fairness of labor practices (Sen and Bhattacharya 2001; Whalen et al. 
1991). In terms of stakeholder theory, a firm displaying a high standard of ethical behavior thus is rewarded by a positive consumer response, which is supported by many studies. For instance, Davidson (1998) proposes that similar to price and quality, an organization's degree of ethical behavior is an important attribute in consumer purchasing decisions. Abratt and Sacks (1988) suggest that consumers avoid transactions with dishonest and unethical organizations. Moreover, consumers are willing to pay more for (Elliott and Freeman 2005), or are more likely to purchase (Auger et al. 2003), products made under ethically responsible conditions. Similarly, Folkes and Kamins (1999) propose that an organization's degree of ethical behavior determines consumer attitudes. Therefore, this stream of literature suggests that an organization's ethical behavior positively influences consumer attitudes in general and, presumably, also customer satisfaction in particular. While this theoretical background is limited to studies from developed countries, we analogously hypothesize that consumer perceptions of a firm's degree of ethical behavior positively influence customer satisfaction in developing countries (H1c)

In terms of signaling theory, a firm's perceived ethical behavior can signal trustworthiness in how the firm treats not only society or employees, but also customers. Signaling low risk to consumers is particularly effective in developing countries, where consumers frequently do not know which firm they can trust (Frank et al. 2013), and thus enhances customer satisfaction.

\section{Effects on customer loyalty $(\mathrm{H} 2)$}

Finally, we seek to understand how the perception of CSR practices affects consumer loyalty. Customer loyalty is considered an attitudinal construct reflecting the customer intention to purchase again from a brand (Frank et al. 2012, 2014). According to Sureshchandar et al. (2002), CSR practices should influence customer loyalty. In terms of signaling theory, a consumer's perception of CSR practices should increase commitment to a brand because these CSR practices signal (a) the brand's character (Brown and Dacin 1997), (b) values differentiating the brand from other brands (Turban and Greening 1997), (c) respect for society in general and customers in particular, and (d) the desire to comply with quality standards (de los Salmones et al. 2005). Based on stakeholder theory, consumers reward these efforts with loyalty towards the organization (Maignan et al. 1999). Different research shows that consumers are willing to buy and repurchase products from organizations associated with social causes (Ross et al. 1992; Frank and Schvaneveldt 2014, 2016; Moisescu 2017). From this stream of literature on developed countries, we infer that perceived CSR practices positively influence customer loyalty, and we posit that these influences are mediated by customer attitudes toward the focal brand.

The most prominent and empirically verified type of customer attitude affecting customer loyalty, and thus the most likely mediator of the effects of CSR practices on customer loyalty, is customer satisfaction (Abulaiti et al. 2010; Johnson et al. 1997; Fornell et al. 2006; Frank et al. 2012, 2014). Not only empirical academic studies, but also large-scale national customer barometers (e.g., the American Customer Satisfaction Index) from developed countries confirm the cross-industry and crosscountry validity of the causal relationship between customer satisfaction and customer loyalty (Fornell et al. 2006). As an extension of the hypothesized influence of CSR practices on customer satisfaction (H1), we thus propose that customer satisfaction mediates an influence of CSR practices on customer loyalty in developing countries (H2). This has not yet been shown in the CSR literature, whose focus is on developed countries.

\section{Methodology}

We tested our hypotheses with a sequential mixedmethods approach (Bryman 2006), the so-called QUANT+qual approach (Morgan 1998). As the dominant research method, we first collected and analyzed quantitative data, which provides a statistical test of our research hypotheses. As a complementary approach frequently used by survey researchers (Morgan 1998), we subsequently collected qualitative data through interviews with Bolivian CSR experts in order to confirm the practical value of our results, to discuss their application in corporate practice, and to obtain further valuable insights beyond the reach of our hypotheses.

\section{Measures}

To test our hypotheses, we developed a questionnaire for a consumer survey. Based on the results of a pilot test, we improved the questionnaire to ensure the reliability and validity of the scales. The questionnaire contained two sections. Section 1 included questions regarding brand-specific CSR practices in the industry context of grocery stores (service industry) or soft drinks (product industry). Section 2 included questions regarding consumer attitudes: customer satisfaction and customer loyalty for the respective industry context. As the intended contribution is to explore the role of CSR practices in the formation of consumer attitudes and behavioral intentions in a developing country, in contrast to the abundance of extant research on developed countries, we chose to focus on Bolivia as the least developed among the developing countries in the Americas (IMF 2017). This choice ensures a clear focus on a developing country and a marked contrast from the known situation in developed countries. 
In terms of product contexts, we focused on consumer perceptions of grocery stores and soft drinks for four reasons. First, we sought to study the benefits of CSR practices as a marketing tool in a real, actually experienced product/service context rather than in an artificial experiment. Second, we chose to focus on multiple brands in a product context and a service context in order to understand the degree to which findings can be generalized across contexts because generalizing purely context-specific results can lead to misinterpretations that are costly to practitioners following research recommendations. Third, due to the multi-dimensionality and complexity of CSR practices (Maignan and Ferrell 2001), consumers in Bolivia and elsewhere have difficulties in acquiring and memorizing information about CSR practices (Mohr et al. 2001), which might impair the validity of results obtained in research. Fourth, we follow recommendations in the marketing literature (Lehmann et al. 2011) to ascertain cross-contextual relevance and its potential boundary conditions. While numerous industries may fit these rationales, we focused on grocery stores and soft drinks as two contexts that are very well known to Bolivian consumers. Moreover, these industries are well known for their investments in CSR practices, and thus, to some extent, consumers feel involved with these CSR practices.

Section 1 of the questionnaire measured three types of CSR practices with 10-point Likert-type scales ranging from 1 (strongly disagree) to 10 (strongly agree). In particular, we measured recycling convenience with three items from Pickett-Baker and Ozaki (2008), e.g., easiness to recycle the product's container. We measured ecofriendly practices with four items from Webb et al. (2007), e.g., manufacturing the product with a minimum use of resources and energy. Finally, we measured ethical behavior with two items based on Schmeltz (2012), e.g., manufacturing the product under socially responsible conditions. Similarly, section 2 of the questionnaire measured customer satisfaction and customer loyalty through multi-item scales with 10-point Likert-type scales from Fornell (1992), e.g., overall satisfaction with the product.

\section{Data collection and sample profile}

Our data collection focused on consumers across Bolivia aged 18 years and older. We conducted a physical, rather than electronic, survey because electronic surveys are not widely used in Bolivia due to unreliable Internet provider service. We collected 489 valid questionnaires for our study on grocery stores. In this sample, $55 \%$ of the respondents were male and $45 \%$ female. Their ages ranged from 18 to 71 years. For our study on soft drinks, we collected 527 valid questionnaires. In this sample, $53 \%$ of the respondents were male and $47 \%$ female, with ages ranging from 18 to 82 years. Both samples had a similar age and gender distribution and thus appeared comparable.

\section{Convergent and discriminant validity}

Following the guidelines proposed by Anderson and Gerbing (1988), our study assessed the adequacy of measurements using a confirmatory factor analysis (CFA) with maximum likelihood estimation. As shown in Table 1, the goodness-of-fit indices in both industries show that the five-factor model has an acceptable fit with the data (grocery stores: $\chi^{2} /$ d.f. $=3.322, p<0.001$, RMSEA $=0.069, \mathrm{CFI}=0.956, \mathrm{NFI}=0.938$; soft drinks: $x^{2}$ / d.f. $=2.473, p<0.001$, RMSEA $=0.053, \mathrm{CFI}=0.968$, NFI $=0.947)$. All items load significantly on their specified latent construct $(p<0.01)$ with loadings above 0.60 . In addition, we calculated the composite reliability (CR) and average variance extracted (AVE) of all constructs to examine their convergent and discriminant validity. The $\mathrm{CR}$ of recycling convenience, eco-friendly practices, ethical behavior, customer satisfaction, and customer loyalty in grocery stores is $0.853,0.818,0.884,0.809$, and 0.839 , respectively. In the case of soft drinks, the $\mathrm{CR}$ of recycling convenience, eco-friendly practices, ethical behavior, customer satisfaction, and customer loyalty are $0.859,0$. $822,0.810,0.801$, and 0.850 , respectively. As shown in

Table 1 Descriptive statistics and psychometric properties of constructs

\begin{tabular}{|c|c|c|c|c|c|c|c|c|}
\hline \multirow[b]{2}{*}{ Measure } & \multicolumn{4}{|c|}{ Grocery stores } & \multicolumn{4}{|c|}{ Soft drinks } \\
\hline & Mean & SD & $C R$ & AVE & Mean & SD & $C R$ & AVE \\
\hline Recycling convenience & 5.740 & 1.947 & 0.853 & 0.774 & 5.927 & 2.382 & 0.859 & 0.673 \\
\hline Eco-friendly practices & 8.891 & 1.666 & 0.818 & 0.530 & 5.934 & 1.924 & 0.822 & 0.537 \\
\hline Ethical behavior & 6.372 & 1.934 & 0.884 & 0.884 & 6.979 & 2.138 & 0.810 & 0.810 \\
\hline Customer satisfaction & 6.664 & 1.423 & 0.809 & 0.586 & 7.269 & 1.466 & 0.801 & 0.520 \\
\hline Customer loyalty & 6.690 & 1.574 & 0.839 & 0.637 & 7.093 & 1.463 & 0.850 & 0.656 \\
\hline \multirow{2}{*}{ Model measurement fit } & $x^{2} /$ d.f. & RMSEA & $\mathrm{CFI}$ & $\mathrm{NFI}$ & $x^{2} /$ d.f. & RMSEA & $\mathrm{CFI}$ & $\mathrm{NFI}$ \\
\hline & 3.322 & 0.069 & 0.956 & 0.938 & 2.473 & 0.053 & 0.968 & 0.947 \\
\hline
\end{tabular}


Table 1, all CR /AVE values exceed the recommended threshold values of 0.7 / 0.5 (Fornell and Larcker 1981), and all AVE values exceed the squared correlation between the focal factor and any other factor. These results confirm the convergent and discriminant validity of our measurement model (see Table 1).

\section{Results of analysis: Hypothesis tests \\ Quantitative data analysis}

Based on the quantitative data obtained through our consumer surveys, we tested our hypotheses using structural equation modeling with maximum likelihood estimation. As shown in Fig. 2, the results suggest that the model fit the data of each industry context appropriately (grocery stores: $\chi^{2} /$ d.f. $=3.288, p<0.001$, RMSEA $=0$. 068, CFI $=0.955, \mathrm{NFI}=0.936$; soft drinks: $x^{2} /$ d.f. $=2.387$, $p<0.001$, RMSEA $=0.051, \mathrm{CFI}=0.969, \mathrm{NFI}=0.947$ ). All hypothesized paths are significant and positive, providing first signs of support for $\mathrm{H} 1-\mathrm{H} 2$. In an alternative regression analysis, we included age, sex, marital status and household size as control variables for both models, which did not lead to any major changes in the path coefficients. An additional multiple group analysis of the data for both industry contexts did not reveal any significant differences among (a) construct measurements $\left(\Delta \mathrm{X}^{2}=13.321, \Delta\right.$ d.f. $\left.=9\right)$ and (b) structural path coefficients (recycling convenience $\rightarrow$ customer satisfaction: $\Delta \chi^{2}=0.257, \Delta$ d.f. $=1$; eco-friendly practices $\rightarrow$ customer satisfaction: $\Delta \mathrm{x}^{2}=2.518, \Delta$ d.f. $=1$; and ethical behavior $\rightarrow$ customer satisfaction: $\Delta \mathrm{X}^{2}=2.087$, $\Delta$ d.f. $=1$ ). Therefore, our results hold across both industry contexts.

In the following step, to test whether customer satisfaction indeed mediates the effects of CSR practices on customer loyalty, as suggested by $\mathrm{H} 2$, we re-estimated the proposed model with three additional, direct (nonmediated) paths from recycling convenience, eco- friendly practices, and ethical behavior to customer loyalty. The revised model shows an adequate, but slightly lower, nominal fit with the data (grocery stores: $\mathrm{X}^{2} / \mathrm{d}$.f. $=$ 3.322, $p<0.001$, RMSEA $=0.053, \mathrm{CFI}=0.956, \mathrm{NFI}=0$. 938; soft drinks: $X^{2} /$ d.f. $=2.473, p<0.001$, RMSEA $=0$. 053, CFI $=0.968, \mathrm{NFI}=0.947$ ). However, all of the additional direct paths from CSR practices to customer loyalty are non-significant for grocery stores, and only one path (from recycling convenience to customer loyalty) is significant $(p<0.01)$ for soft drinks. Despite the additional path, there is no significant chi-square difference between the hypothesized model and the extended model (grocery stores: $\Delta \mathrm{X}^{2}=7.599, \Delta$ d.f. $=3$; soft drinks: $\Delta x^{2}=0.272, \Delta$ d.f. $=3$ ). Thus, we decided to consider our originally hypothesized model for all subsequent analyses. Independent of whether recycling convenience has an additional effect on customer loyalty, the results indicate that customer satisfaction mediates the effects of CSR practices on customer loyalty (H2). Moreover, we estimated a model without customer satisfaction, only with direct paths from CSR practices to customer loyalty. As verified by Sobel tests, all of these path coefficients become significantly weaker when adding customer satisfaction to the model (grocery stores: $\mathrm{Z}_{\text {recycling convenience }}=7.071, p<0.01 ; \mathrm{Z}_{\text {eco-friendly practices }}=$ $9.714, \quad p<0.01 ; \quad Z_{\text {ethical }}$ behavior $=10.404, p<0.01 ;$ soft drinks: $\mathrm{Z}_{\text {recycling }}$ convenience $=4.345, p<0.01 ; \mathrm{Z}_{\text {eco-friendly }}$ practices $=5.455, p<0.01 ; Z_{\text {ethical behavior }}=7.469, p<0.01$ ). These results provide evidence of the hypothesized mediating role of customer satisfaction $(\mathrm{H} 2)$.

As Fig. 2 shows in detail, the results for both industries support the hypothesized effects of recycling convenience $\left(\mathrm{H} 1 \mathrm{a}\right.$ : $\beta_{\text {grocery stores }}=0.201, p<0.01 ; \beta_{\text {soft drinks }}=$ $0.123, p<0.05)$ and ethical behavior $\left(\mathrm{H} 1 \mathrm{c}: \beta_{\text {grocery stores }}=\right.$ $\left.0.439, p<0.01 ; \beta_{\text {soft drinks }}=0.367, p<0.01\right)$ on customer satisfaction. They partially support the hypothesized effect of eco-friendly practices ( $\mathrm{H} 1 \mathrm{~b}$ : $\beta_{\text {grocery stores }}=0.070$,

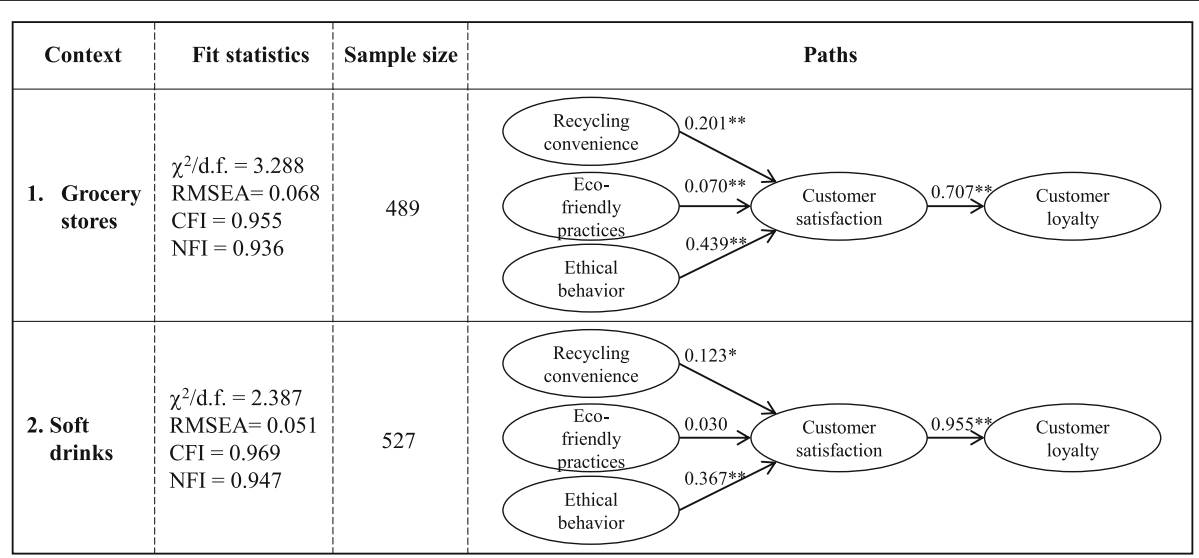

Notes: ${ }^{*} p<0.05 ;{ }^{*} p<0.01$

Fig. 2 Results of structural models for grocery stores and soft drinks 
$\left.p<0.01 ; \beta_{\text {soft drinks }}=0.030, p>0.05\right)$ on customer satisfaction. Fig. 2 also indicates a significant positive influence of customer satisfaction on customer loyalty for both industry contexts $\left(\mathrm{H} 2\right.$ : $\beta_{\text {grocery stores }}=0.707, p<0$. $\left.01 ; \beta_{\text {soft drinks }}=0.955, p<0.01\right)$.

\section{Qualitative data analysis}

To complement our analyses and to obtain information not accessible through quantitative analysis, we interviewed five Bolivian CSR experts regarding the meaning and implementation of CSR practices in Bolivia. The experts were selected based on recommendations from the Observatory on Corporate Social Responsibility in Cochabamba, Bolivia. Most of the experts conceptualized CSR practices as a management system that allows organizations to manage environmental, social, and economic business processes for continual improvement. These experts agreed that firms implement CSR practices in Bolivia, but only partially in the sense that they focus on environmental dimensions such as eco-friendly practices, whereas they tend to overlook social dimensions of ethical conduct such as responsible labor practices. For example, many firms engage in unfair labor practices that do not comply with Bolivian labor law. In particular, one expert explained the following:

In Bolivia, the existence of monopolies prevents CSR practices from transcending current business practices. Therefore, firms can mistreat their employees, and those employees have to endure abuses to not lose their jobs.

This finding is intriguing because our quantitative analysis shows extremely strong effects of labor-related ethical behavior on customer satisfaction and customer loyalty (see Fig. 2). Compared with the status quo, a greater focus on ethical behavior thus would have the potential to pay off. In addition, the experts pointed out that young managers with access to a more international education and to best practices from developed countries are raising the level of CSR awareness and advocating the use of eco-friendly business processes in Bolivia.

Based on hands-on business experience and actual marketing practitioner insights, the CSR experts also suggested that CSR practices indeed would influence customer loyalty in Bolivia, as hypothesized in our study $(\mathrm{H} 1-\mathrm{H} 2)$. Specifically, the experts suggested that Bolivian consumers value a firm's perceived honesty because this honesty increases both consumer' trust in a market where still not every firm can be trusted and their consequential repurchase intentions. In these descriptions, the experts conceptualized a firm's honesty as true compliance of products or services with consumer requirements and as true statements about the degree of compliance. For example, one expert explained:
Nowadays, very few firms consider the changes caused by CSR practices on consumers, maybe only in the banking industry. However, CSR practices help to improve consumer attitudes. Transparency and sincerity with the consumer allow the firm to earn the consumer's loyalty and make him or her satisfied.

Furthermore, the CSR experts suggested that consumers feel inherent satisfaction when purchasing from socially conscious firms because consumers are satisfied with the values that these firms represent. In addition, the CSR experts proposed that CSR practices would improve over time in Bolivia because younger consumers are socially conscious and would demand eco-friendly products and services as they become older and grow in purchasing power and market influence. Finally, two of the five experts suggested that the Bolivian agribusiness industry currently is working on inclusive businesses, which are sustainable businesses aiming to benefit lowincome communities. One of these experts explained:

CSR practices are correctly applied in the agribusiness industry in the form of inclusive businesses that allow small firms to participate in the market. Most of their practices are oriented to take care of the environment.

Moreover, all CSR experts agreed that multinational organizations, such as Unilever and The Coca-Cola Company are leading the way in implementing CSR practices in Bolivia. Specifically, one expert suggested:

The implementation of CSR practices is led by big firms that belong to multinational organizations, such as Unilever, The Coca-Cola Company, or Bata. They are currently implementing different CSR programs oriented towards the Bolivian society. However, other firms have no incentive to use CSR practices. Those firms perceive CSR practices as an expense and not as a competitive weapon. In the future, little by little firms will realize that CSR practices can appeal to the consumer, open new markets, and thus help improve profitability.

\section{Discussion and theoretical implications} Discussion

To address the literature gap on CSR in developing countries, our study aims to increase the understanding of the effects of CSR practices on consumer attitudes, such as customer satisfaction and customer loyalty, in developing countries using the case of Bolivia, which is the least developed among the developing countries in the Americas (IMF 2017). In particular, this is the first such empirical study on the effects of CSR in Bolivia, 
which - like many developing countries - still lags behind in building a strongly research-oriented university system.

Using structural equation modeling of quantitative data from two industry contexts, we explore the direct [indirect] relationships of recycling convenience, ecofriendly practices, and ethical behavior with customer satisfaction [customer loyalty]. With the exception of a single non-significant path in the soft drink context (from eco-friendly practices to customer satisfaction: $\beta_{\text {soft drinks }}=0.030, p>0.05$ ), our findings support the hypothesized linkages among the study constructs (H1$\mathrm{H} 2$ ).

The results of our complementary qualitative data analysis support the quantitative findings. Similar to our quantitative results, interviews with Bolivian CSR experts confirmed the influence of CSR practices on customer satisfaction (H1) and customer loyalty (H2). These experts also confirmed that CSR practices lead to intrinsic satisfaction with the firm's values and thus that customer satisfaction mediates the effects of CSR practices on customer loyalty $(\mathrm{H} 2)$. Hence, we found theoretical and empirical coherence between the qualitative and quantitative results.

In addition, the CSR experts proposed a role of trust as an additional mediator of the relationship between CSR practices and customer loyalty. Their argumentation suggests that CSR practices signal honesty, which helps build trust within the frequently non-trustworthy market environment of a developing country and thus is effective in influencing customer loyalty. This qualitative result appears to be of special importance to our studied context of developing countries and corresponds with reasons for an enhanced importance of brand reputation in developing countries (Frank et al. 2013). As additional insights, the CSR experts reported that Bolivian firms focus more on environmental than social CSR practices, that young managers and multinational firms are leading the way in implementing and promoting CSR practices, and that younger consumers drive increasing demand for products and services from ethically responsible firms. These results correspond with recent findings of a greater importance of value identification for younger consumers (Herbas Torrico and Frank 2018), which our results thus may extend to CSR contexts.

\section{Theoretical implications}

Through the theoretical lenses of signaling theory and stakeholder theory, our conceptual framework and empirical results contribute to a better understanding of the effects of CSR practices in developing countries.

Based on signaling theory, our study suggests that CSR practices enable firms to signal intangible capabilities to consumers (also Frombrun et al. 2000; Su et al. 2016), which we posited to be of particular importance in the less transparent environment of developing countries, where information access is limited and information frequently is not trustworthy (Miller et al. 2009). Such intangible capabilities include a better understanding of consumer concerns, a higher capability to create value for consumers and society $(\mathrm{H} 1 \mathrm{a} / \mathrm{b}$ : recycling convenience, eco-friendly practices), advanced technological capabilities (H1b: eco-friendly practices), and a low purchase risk from cheating and hidden quality problems (H1c: ethical behavior). CSR practices are very effective in signaling such capabilities because they make apparent the firm's willingness to incur higher costs now in order to create future benefits for customers and society at large (Moore 2002). The use of such signals leads to a positive customer response reflected by higher levels of customer satisfaction and customer loyalty (H2), and thus has the potential to translate into long-term financial benefits (Frank et al. 2009).

Based on stakeholder theory, our study suggests that CSR practices are especially effective at addressing stakeholder concerns in developing countries, where the negative effects of corporate behavior on society frequently are especially pronounced (Ward et al. 2007). Addressing such stakeholder concerns leads to positive stakeholder responses, such as higher levels of customer satisfaction (H1) and customer loyalty $(\mathrm{H} 2)$ in case of customers as a firm's most important stakeholder group, and thus can benefit the firm in the long term. In order to reap beneficial stakeholder responses, firms need to focus on CSR practices of particular relevance to developing countries, such as recycling convenience (H1a: lack of infrastructure in developing countries), ecofriendly practices ( $\mathrm{H} 1 \mathrm{~b}$ : prevalent environmental pollution in developing countries), and ethical behavior (H1c: prevalent customer cheating due to weaker consumer protection and government supervision in developing countries). At the same time, it is important that firms not only promise CSR practices, but also keep such promises. Otherwise, stakeholders might condemn firms as being hypocritical and misleading, and thus might react negatively, rather than positively, to promised CSR practices (Chen et al. 2014).

Regarding our empirical results, a nominal comparison of the effects of distinct CSR types on customer satisfaction indicates consistently for both industry contexts that ethical behavior has the strongest effect, followed by recycling convenience and eco-friendly behavior. As ethical behavior primarily concerns social and labor conditions, this result may indicate that consumers in developing countries most strongly focus on still unmet social needs, whereas environmental needs are only secondary. By contrast, social needs more or less tend to be met in developed countries, where environmental CSR 
appears to be more effective as a differentiator (Khanna et al. 2005).

\section{Managerial implications and future research}

Our quantitative and qualitative results suggest that CSR practices directly influence customer satisfaction and indirectly influence customer loyalty for Bolivian consumers. This result has the following managerial implications.

First, our study suggests that not only in developed countries, but also in developing countries, consumers account for a brand's CSR practices when evaluating its products and services (H1). Therefore, in order to increase customer satisfaction, firms should behave ethically because consumers are willing to pay higher prices or show different signs of loyalty as a way to reward the firm's ethical behavior. Specifically, according to Creyer and Ross (1997), in order to behave ethically, organizations should subscribe to values such as transparency, honesty, and humility.

Second, our study finds that recycling convenience is an important antecedent of customer satisfaction in a developing country context where limitations in financial resources often make harmless disposal and waste treatment practices difficult (H1a). This finding suggests that organizations not only should consider the use of recyclable materials when designing a product, but they also should ease the recycling process for the consumer. For example, Domina and Koch (2002) suggest that consumers are willing to recycle a wider variety of waste when the system is more convenient. Therefore, firms in developing countries should develop recycling systems that make recycling a convenient activity. For example, municipalities could implement curbside collection days for recyclable products.

Third, our results show that eco-friendly practices influence customer satisfaction in a developing country context where environmental degradation frequently is a problem (H1b). This suggests that consumers in developing countries indeed are aware of the influence of their own purchase behavior on the environment. Therefore, as Han et al. (2009) proposed, organizations actively should inform less environmentally conscious groups that eco-friendly purchasing exerts a positive influence on the environment, and convince them that protecting the environment is everyone's responsibility. These campaigns would motivate consumers to engage in eco-friendly activities, strengthen their intentions to purchase eco-friendly products, and thus increase their satisfaction.

Fourth, we find that ethical behavior influences customer satisfaction in a developing country context where ethical standards in labor practices, product safety, and social contributions tend to be lower than in developed countries (H1c). Therefore, our results suggest that organizations in developing countries should consider behaving ethically to their own benefit. While unethical behavior might be motivated by cost-cutting and increased short-term profits through cheating, a negative stakeholder reaction to such behavior may offset all apparent profit-related benefits of unethical behavior. Due to the stakeholder reaction by consumers, ethical behavior should increase a firm's market share because consumers perceive the firm's products as being made under ethically impeccable conditions and reward the firm through higher purchases (Auger et al. 2003). As the CSR experts in our qualitative study suggested, Bolivian firms currently are breaching the labor law. Thus, in order to behave ethically and increase customer satisfaction, such firms first should comply with the labor law, especially since ethical behavior consistently has the strongest effect on customer satisfaction across product categories in our quantitative study.

Of particular note, our consistent finding across categories of a greater role of ethical behavior and a smaller role of environmental CSR in our developing country context of Bolivia is especially intriguing because the results of our qualitative study indicate that Bolivian firms follow the opposite strategy of focusing more on environmental CSR and less on social or labor-related ethical behavior. Our results thus suggest a need for Bolivian firms with limited resources for CSR to rethink and to align their CSR activities with consumer priorities for ethical behavior, rather than prioritize environmental CSR.

Fifth, our results show that CSR practices indirectly influence customer loyalty through customer satisfaction (H2). Similar to de los Salmones et al. (2005), this finding suggests that CSR practices do influence customer loyalty, or purchase behavior in general, via the customer's overall evaluation of the product or service. Therefore, in order to make profits from consumer purchases, firms in developing countries should link their economic orientation with a social orientation. Specifically, such firms should have well-defined codes of ethics and a clear philosophy of social commitment, have respect for the environment, and show honesty. Moreover, firms from developing countries should subscribe to international codes in order to both formalize their policies and improve through benchmarking themselves against organizations in other developing or even developed countries. In addition, firms in developing countries should communicate their social orientation and environmental involvement using the Internet. For example, organizations can use both social media and mass media to inform society about their CSR practices. The use of the Internet reduces costs, which is of crucial importance in developing countries. 
Finally, our qualitative results also show that local firms in a developing country lag behind multinationals. Therefore, local firms and the government should enforce the use of CSR practices to improve operations and thus increase customer satisfaction.

This study had many limitations. For example, we collected data from only two industries. Future studies should collect data from other industries to validate and improve our model. Moreover, future research can study the influence of cultural factors on the importance of the CSR practices included in our model. As typical for developing countries with a traditional economic structure, Bolivia is characterized by traditional values. Thus, we propose that future studies account for the moderating effect of tradition in analyzing the effects of CSR practices.

In order to address the lack of CSR studies in developing countries in general and in Bolivia/Latin America in particular, our work is an attempt to provide new ideas about the consequences and meanings of CSR practices in a developing country context with a still low level of development. We hope that our study stimulates new research to deepen the understanding of the commercial implications of CSR practices for firms in developing countries.

\section{Abbreviations}

AVE: Average variance extracted; CFI: Comparative fit index; CR: Composite reliability; CSR: Corporate social responsibility; d.f.: Degrees of freedom; NFI: Normed fit index; RMSEA: Root mean square error of approximation; SD: Standard deviation

\section{Acknowledgments}

The authors thank all survey respondents. They also thank two anonymous reviewers for their constructive and helpful comments.

\section{Funding}

The authors gratefully acknowledge government financial support from KAKENHI (grant no. 15H05395). Moreover, they thank the administrative and financial support given by the Bolivian Catholic University.

\section{Availability of data and materials}

In order to avoid social desirability bias and to comply with both privacy laws and privacy-related university regulations, the process of data collection promised to all respondents that their raw data would not be shared with any third parties.

\section{Authors' contributions}

BHT contributed to survey design, data collection, data analysis, and article writing. BF contributed to survey design and article writing. CAT contributed to data collection, data analysis, and article writing. All authors read and approved the final manuscript.

\section{Authors' information}

Boris Herbas Torrico is Professor and Carlos Arandia Tavera is a student at the Bolivian Catholic University in Cochabamba, Bolivia. Björn Frank is Associate Professor at Waseda University in Tokyo, Japan. Boris Herbas Torrico and Björn Frank both hold doctoral degrees in industrial engineering and management obtained from the Tokyo Institute of Technology.

\section{Competing interests}

The authors declare that they have no competing interests.

\section{Publisher's Note}

Springer Nature remains neutral with regard to jurisdictional claims in published maps and institutional affiliations.

\section{Author details}

${ }^{1}$ Department of Industrial Engineering, Bolivian Catholic University San Pablo, M. Marquez Street and Jorge Trigo Andia Park - Tupuraya, Cochabamba,

Bolivia. ${ }^{2}$ Graduate School of Commerce, Waseda University, 1-6-1

Nishi-Waseda, Shinjuku-ku, Tokyo 169-8050, Japan.

Received: 9 October 2017 Accepted: 25 March 2018

Published online: 25 April 2018

\section{References}

Abratt, R., \& Sacks, D. (1988). The marketing challenge: Towards being profitable and socially responsible. Journal of Business Ethics, 7(7), 497-507.

Abulaiti, G., Enkawa, T., \& Frank, B. (2010). Influences of the economic crisis on customer attitudes and the moderating role of culture. Journal of the Japanese Society for Quality Control, 40, 225-233.

Ali, W., Frynas, J., \& Mahmood, Z. (2017). Determinants of corporate social responsibility (CSR) disclosure in developed and developing countries: A literature review. Corporate Social Responsibility and Environmental Management, 24(4), 273-294.

Anderson, J. C., \& Gerbing, D. W. (1988). Structural equation modeling in practice: A review and recommended two-step approach. Psychological Bulletin, 103(3), 411-423.

Ando, A. W., \& Gosselin, A. Y. (2005). Recycling in multifamily dwellings: Does convenience matter? Economic Inquiry, 43(2), 426-438.

Arnould, E. J., \& Thompson, C. J. (2005). Consumer culture theory (CCT): Twenty years of research. Journal of Consumer Research, 31(4), 868-882.

Auger, P., Burke, P., Devinney, T. M., \& Louviere, J. J. (2003). What will consumers pay for social product features? Journal of Business Ethics, 42(3), 281-304.

Barnes, D., Hinton, M., \& Mieczkowska, S. (2005). Enhancing customer service operations in e-business: The emotional dimension. Journal of Electronic Commerce in Organizations, 3(2), 17-32.

Berman, S. L., Wicks, A. C., Kotha, S., \& Jones, T. M. (1999). Does stakeholder orientation matter? The relationship between stakeholder management models and firm financial performance. Academy of Management Journal, 42(5), 488-506.

Berry, L., Seiders, K., \& Grewel, D. (2002). Understanding service convenience. Journal of Marketing, 66(3), 1-17.

Bhattacharya, C. B. (2009). Corporate social responsibility: It's all about marketing. https://www.forbes.com/2009/11/20/corporate-social-responsibilityleadership-citizenshipmarketing.html. Accessed 3 May 2017.

Bhattacharya, C. B., \& Sen, S. (2004). Doing better at doing good: When, why, and how consumers respond to corporate social initiatives. California Management Review, 47(1), 9-24.

Biswas, A., Licata, J. W., McKee, D., Pullig, C., \& Daughtridge, C. (2000). The recycling cycle: An empirical examination of consumer waste recycling and recycling shopping behaviors. Journal of Public Policy \& Marketing, 19(1), 93-105.

Bowen, H. R. (1953). Social responsibilities of the businessman. New York: Harper \& Brothers.

Brown, T. (1998). Corporate associations in marketing: Antecedents and consequences. Corporate Reputation Review, 1(3), 215-233.

Brown, T. J., \& Dacin, P. A. (1997). The company and the product: corporate associations and consumer product responses. Journal of Marketing, 61(1), 68-84.

Bryman, A. (2006). Integrating quantitative and qualitative research: How is it done? Qualitative Research, 6(1), 91-113.

Castaldo, S., Perrini, F., Misani, N., \& Tencati, A. (2009). The missing link between corporate social responsibility and consumer trust: The case of fair trade products. Journal of Business Ethics, 84(1), 1-15.

Cetindamar, D. (2007). Corporate social responsibility practices and environmentally responsible behavior: The case of the United Nations global compact. Journal of Business Ethics, 76(2), 163-176.

Chen, Y. S., Lin, C. L., \& Chang, C. H. (2014). The influence of greenwash on green word-of-mouth (green WOM): The mediation effects of green perceived quality and green satisfaction. Quality \& Quantity, 48(5), 2411-2425.

Chung, K., Yu, J., Choi, M., \& Shin, J. (2015). The effects of CSR on customer satisfaction and loyalty in China: The moderating role of corporate image. Journal of Economics, Business and Management, 3(5), 542-547. 
Connelly, B., Certo, S., Ireland, R., \& Reutzel, C. (2011). Signaling theory: A review and assessment. Journal of Management, 37(1), 39-67.

Creyer, E. H., \& Ross, W. T. J. (1997). The influence of firm behaviour on purchase intention: Do consumers really care about business ethics? Journal of Consumer Marketing, 14(6), 421-432.

Davidson, D. K. (1998). Who cares? Proceedings of the International Association for Business and Society, 9, 743-754.

de los Salmones, M. D. M. G., Crespo, A. H., \& del Bosque, I. R. (2005). Influence of corporate social responsibility on loyalty and valuation of services. Journal of Business Ethics, 61(4), 369-385.

de Olivera, J. A. (2006). Corporate citizenship in Latin America: New challenges for business. Journal of Corporate Citizenship, 21, 17-20.

Doh, J., Husted, B. W., \& Yang, X. (2016). Guest editors' introduction: Ethics, corporate social responsibility, and developing country multinationals. Business Ethics Quarterly, 26(3), 301-315.

Domina, T., \& Koch, K. (2002). Convenience and frequency of recycling: Implications for including textiles in curbside recycling programs. Environment and Behavior, 34(2), 216-238.

Elliott, K. A., \& Freeman, R. B. (2005). White hats or don Quixotes? Human rights vigilantes in the global economy. In R. B. Freeman, J. Hersch, \& L. Mishel (Eds. ), Emerging labor market institutions for the twenty-first century (pp. 47-97). Chicago, IL: University of Chicago Press.

Folkes, V., \& Kamins, M. (1999). Effects of information about firms' ethical and unethical actions on consumers' attitudes. Journal of Consumer Psychology, 8(3), 243-259.

Fornell, C. (1992). A national customer satisfaction barometer: The Swedish experience. Journal of Marketing, 56(1), 6-21.

Fornell, C., \& Larcker, D. F. (1981). Evaluating structural equation models with unobservable variables and measurement error. Journal of Marketing Research, 18(1), 39-50.

Fornell, C., Mithas, S., Morgeson III, F. V., \& Krishnan, M. S. (2006). Customer satisfaction and stock prices: High returns, low risk. Journal of Marketing, 70(1), 3-14.

Frank, B., Abulaiti, G., \& Enkawa, T. (2012). What characterizes Chinese consumer behavior? A cross-industry analysis of the Chinese diaspora in Japan. Marketing Letters, 23(3), 683-700.

Frank, B., Abulaiti, G., Herbas Torrico, B., \& Enkawa, T. (2013). How do Asia's two most important consumer markets differ? Japanese-Chinese differences in customer satisfaction and its formation. Journal of Business Research, 66(12), 2397-2405.

Frank, B., Herbas Torrico, B., Enkawa, T., \& Schvaneveldt, S. J. (2014). Affect versus cognition in the chain from perceived quality to customer loyalty: The roles of product beliefs and experience. Journal of Retailing, 90(4), 567-586.

Frank, B., \& Schvaneveldt, S. J. (2014). Self-preservation vs. collective resilience as consumer responses to national disasters: A study on radioactive product contamination. Journal of Contingencies and Crisis Management, 22(4), 197-208.

Frank, B., \& Schvaneveldt, S. J. (2016). Understanding consumer reactions to product contamination risks after national disasters: The roles of knowledge, experience, and information sources. Journal of Retailing and Consumer Services, 28, 199-208.

Frank, B., Sudo, S., \& Enkawa, T. (2009). Interpreting time series of patient satisfaction: Macro vs. micro components. Journal of Hospital Marketing \& Public Relations, 19(1), 15-39.

Freeman, R. E. (1994). The politics of stakeholder theory: Some future directions. Business Ethics Quarterly, 4(4), 409-421.

Frombrun, C., Gardberg, N., \& Barnett, M. (2000). Opportunity platforms and safety nets: Corporate citizenship and reputational risk. Business and Society Review, 105(1), 85-106.

Frynas, J., \& Yamahaki, C. (2016). Corporate social responsibility: Review and roadmap of theoretical perspectives. Business Ethics: A European Review, 25(3), 258-285.

Gray, R., Kouhy, R., \& Lavers, S. (1995). Constructing a research database of social and environmental reporting by UK companies. Accounting, Auditing \& Accountability Journal, 8(2), 78-101.

Griffin, J. J., \& Mahon, J. F. (1997). The corporate social performance and corporate financial performance debate. Business \& Society, 36(1), 5-31.

Haddock-Fraser, J., \& Tourelle, M. (2010). Corporate motivations for environmental sustainable development: Exploring the role of consumers in stakeholder engagement. Business Strategy and the Environment, 19(8), 527-542.

Han, H., Hsu, L. T. J., \& Lee, J. S. (2009). Empirical investigation of the roles of attitudes toward green behaviors, overall image, gender, and age in hotel customers' eco-friendly decision-making process. International Journal of Hospitality Management, 28(4), 519-528.
Handelman, J., \& Arnold, S. (1999). The role of marketing actions with a social dimension: Appeals to the institutional environment. Journal of Marketing, 63(3), 33-48.

Haslam, P. (2007). The corporate social responsibility system in Latin America and the Caribbean. http://focal.ca/pdf/csr_04.pdf. Accessed 10 May 2017.

Herbas Torrico, B., \& Frank, B. (2018). Consumer desire for personalization of products and services: Cultural antecedents and consequences for customer evaluations. Total Quality Management \& Business Excellence, forthcoming, https://doi.org/10.1080/14783363.2017.1304819.

Hossain, M., Momin, M., Rowe, A., \& Quaddus, M. (2017). Corporate social and environmental reporting practices: A case of listed companies in Bangladesh. Sustainability Accounting, Management and Policy Journal, 8(2), 138-165.

IMF (2017). World economic and financial surveys. http://www.imf.org/external/ pubs/ft/weo/2017/01/weodata/index.aspx. Accessed 16 September 2017.

Jamali, D., Lund-Thomsen, P., \& Khara, N. (2017). CSR institutionalized myths in developing countries. Business \& Society, 56(3), 454-486.

Johnson, M. D., Herrmann, A., Huber, F., \& Gustafsson, A. (1997). Customer retention in the automotive industry: Quality, satisfaction and loyalty. Wiesbaden: Gabler Verlag.

Kalafatis, S. P., Pollard, M., East, R., \& Tsogas, M. H. (1999). Green marketing and Ajzen's theory of planned behaviour: A cross-market examination. Journal of Consumer Marketing, 16(5), 441-460.

Khanna, T., Palepu, K. G., \& Sinha, J. (2005). Strategies that fit emerging markets. Harvard Business Review, 83(6), 63-74.

Laroche, M., Bergeron, J., \& Barbaro-Forleo, G. (2001). Targeting consumers who are willing to pay more for environmentally friendly products. Journal of Consumer Marketing, 18(6), 503-520.

Lehmann, D., McAllister, L., \& Staelin, R. (2011). Sophistication in research in marketing. Journal of Marketing, 75(4), 155-165.

Luo, X., \& Bhattacharya, C. B. (2006). Corporate social responsibility, customer and satisfaction, and market value. Journal of Marketing, 70(4), 1-18.

Maignan, I., \& Ferrell, O. C. (2001). Corporate citizenship as a marketing instrument: Concepts, evidence and research directions. European Journal of Marketing, 35(3/4), 457-484

Maignan, I., Ferrell, O. C., \& Hult, G. T. M. (1999). Corporate citizenship: Cultural antecedents and business benefits. Journal of the Academy of Marketing Science, 27(4), 455-469.

Manaktola, K., \& Jauhari, V. (2007). Exploring consumer attitude and behaviour towards green practices in the lodging industry in India. International Journal of Contemporary Hospitality Management, 19(5), 364-377.

Mandhachitara, R., \& Poolthong, Y. (2011). A model of customer loyalty and corporate social responsibility. Journal of Services Marketing, 25(2), 122-133.

Miller, D., Lee, J., Chang, S., \& Le Breton-Miller, I. (2009). Filling the institutional void: The social behavior and performance of family vs non-family technology firms in emerging markets. Journal of International Business Studies, 40(5), 802-817.

Minton, A. P., \& Rose, R. L. (1997). The effects of environmental concern on environmentally friendly consumer behavior: An exploratory study. Journal of Business Research, 40(1), 37-48.

Mobley, A. S., Painter, T. S., Untch, E. M., \& Rao Unnava, H. (1995). Consumer evaluation of recycled products. Psychology \& Marketing, 12(3), 165-176.

Mohr, L. A., Webb, D. J., \& Harris, K. E. (2001). Do consumers expect companies to be socially responsible? The impact of corporate social responsibility on buying behavior. Journal of Consumer Affairs, 35(1), 45-72.

Moisescu, O. (2017). From CSR to customer loyalty: An empirical investigation in the retail banking industry of a developing country. Scientific Annals of Economies and Business, 64(3), 307-323.

Moore, D. H. (2002). A signaling theory of human rights. Northwestern University Law Review, 97(2), 879-911.

Morgan, D. L. (1998). Practical strategies for combining qualitative and quantitative methods: Applications to health research. Qualitative Health Research, 8(3), 362-376.

Pickett-Baker, J., \& Ozaki, R. (2008). Pro-environmental products: Marketing influence on consumer purchase decision. Journal of Consumer Marketing, 25(5), 281-293.

Pisani, N., Kourula, A., Kolk, A., \& Meijer, R. (2017). How is international CSR research? Insights and recommendations from a systematic review. Journal of World Business, 52(5), 591-614.

Porter, M. E., \& van der Linde, C. (1995). Toward a new conception of the environment-competitiveness relationship. Journal of Economic Perspectives, 9(4), 97-118. 
Quazi, A., \& O'Brien, D. (2000). An empirical test of a cross-national model of corporate social responsibility. Journal of Business Ethics, 25(1), 33-51.

Rahman, A. (2008). Corporate social responsibility reporting in developing countries: The case of Bangladesh. Hampshire, U.K.: Ashgate.

Roberts, J. A. (1995). Profiling levels of socially responsible consumer behavior: A cluster analytic approach and its implications for marketing. Journal of Marketing Theory and Practice, 3(4), 97-117.

Ross, J. K., Patterson, L., \& Stutts, M. A. (1992). Consumer perceptions of organizations that use cause-related marketing. Journal of the Academy of Marketing Science, 20(1), 93-97.

Rudell, F. (2006). Shopping with a social conscience: Consumer attitudes toward sweatshop labor. Clothing and Textiles Research Journal, 24(4), 282-296.

Sanchez, P. (2016). Responsabilidad social empresarial en Bolivia. http:// nuevaeconomia.com.bo/gne.com.bo/?p=1729. Accessed 6 January 2017.

Schmeltz, L. (2012). Consumer-oriented CSR communication: Focusing on ability or morality? Corporate Communications, 17(1), 29-49.

Sen, S., \& Bhattacharya, C. B. (2001). Does doing good always lead to doing better? Consumer reactions to corporate social responsibility. Journal of Marketing Research, 38(2), 225-243.

Sidique, S. F., Lupi, F., \& Joshi, S. V. (2010). The effects of behavior and attitudes on drop-off recycling activities. Resources, Conservation and Recycling, 54(3), 163-170.

Srivastava, M., \& Kaul, D. (2014). Social interaction, convenience and customer satisfaction: The mediating effect of customer experience. Journal of Retailing and Consumer Services, 21(6), 1028-1037.

Su, W., Peng, M., Tan, W., \& Cheung, Y. (2016). The signaling effect of corporate social responsibility in emerging economies. Journal of Business Ethics, 134(3), 479-491.

Sureshchandar, G. S., Rajendran, C., \& Anantharaman, R. N. (2002). The relationship between service quality and customer satisfaction: A factor specific approach. Journal of Services Marketing, 16(4), 363-379.

Surroca, J., Tribó, J. A., \& Waddock, S. (2010). Corporate responsibility and financial performance: The role of intangible resources. Strategic Management Journal, $31(5), 463-490$

Turban, D. B., \& Greening, D. W. (1997). Corporate social performance and organizational attractiveness to prospective employees. Academy of Management Journal, 40(3), 658-672.

Vining, J., \& Ebreo, A. (1990). What makes a recycler? A comparison of recyclers and nonrecyclers. Environment and Behavior, 22(1), 55-73.

Wang, Z., Zhang, B., Yin, J., \& Zhang, X. (2011). Willingness and behavior towards e-waste recycling for residents in Beijing city, China. Journal of Cleaner Production, 19(9), 977-984

Ward, H., Fox, T., Wilson, E., \& Zarsky, L. (2007). CSR and developing countries: What scope for government action? http://pubs.iied.org/pdfs/G02247.pdf. Accessed 12 June 2017.

Webb, D. J., Mohr, L. A., \& Harris, K. E. (2007). A re-examination of socially responsible consumption and its measurement. Journal of Business Research, 61(2), 91-98.

Whalen, J., Pitts, R. E., \& Wong, J. K. (1991). Exploring the structure of ethical attributions as a component of the consumer decision model: The vicarious versus personal perspective. Journal of Business Ethics, 10(4), 285-293.

\section{Submit your manuscript to a SpringerOpen ${ }^{\circ}$ journal and benefit from:}

- Convenient online submission

- Rigorous peer review

- Open access: articles freely available online

- High visibility within the field

- Retaining the copyright to your article

Submit your next manuscript at $\gg$ springeropen.com 